\title{
Antygenderowe perpetuum mobile
}

Wojciech Śmieja 


\section{Antygenderowe perpetuum mobile ${ }^{1}$}

Wojciech Śmieja

TEKSTY DRUGIE 2017, NR 4, S. 159-165
Praca finansowana przez

Narodowe Centrum

Nauki w ramach grantu MAESTRO 4, 2013/08/A/ HS2/00058: Męskość wliteraturze $i$ kulturze polskiej XIXiXXwieku.

DOI: $10.18318 /$ td.2017.4.10

D la badaczy zajmujących się problematyką gender praca Macieja Dudy to pozycja obowiązkowa, dla zdezorientowanych chaosem medialnym wokół gender Dogmat ptci stanowi znakomity przewodnik i wprowadzenie w istotę zagadnienia, natomiast właściwym adresatem tej książki są ci, którzy jej z pewnością nie przeczytają - głośni „antygenderyści”: księża Dariusz Oko i Paweł Bortkiewicz (ten ostatni to członek Narodowej Rady Rozwoju przy prezydencie Andrzeju Dudzie), samozwańcza "prawnik” Beata Kempa, rozkrzyczana posłanka Krystyna Pawłowicz i wszyscy ci, którzy w imię tzw. tradycyjnych wartości uznają gender (czymkolwiek by ów gender był) za największe zło dzisiejszych czasów.

Czy to, że książka nie zostanie przeczytana przez osoby, które, choćby w imię rzetelności naukowej², powinny

1 Recenzja książki: M. Duda Dogmat płci. Polska wojna z gender, Wydawnictwo Naukowe Katedra, Gdańsk 2016.

2 Np. ksiądz Dariusz Oko wygłasza „wykłady”, a stopień naukowy legitymizuje w salkach przyparafialnych jego wywody jako naukowe właśnie.

\section{Wojciech Śmieja}

(ur. 1977) - dr hab., pracownik Instytutu Nauk o Literaturze Polskiej im. Ireneusza Opackiego na Uniwersytecie Śląskim w Katowicach.

Zajmuje się literaturą XX i XXI wieku. Ostatnio opublikował Homoseksualność i polska nowoczesność. Szkice o teorii, historii i literaturze (2015), Hegemonia i trauma. Literatura wobec dominujacych fikcji męskości (2017). Kontakt:wojsmi@ wp.pl 
po nią sięgnąć, tak jak Duda sięgnął po ich wypowiedzi, przesądza o fiasku przedsięwzięcia szczecińskiego polonisty? Nie. Podobnie jak to, że Marcowe gadanie nie stanowiło trzeźwiącej lektury dla gomułkowskich propagandystów nie zmieniało faktu, że książka ta jest pracą niezwykle ważną - nie tylko naukowo, ale także społecznie. Przywołuję kontekst słynnej pracy Michała Głowińskiego nieprzypadkowo. Jego analizy języka władzy PRL choć nie zmieniły zasad jego funkcjonowania, to obnażyły mechanizmy, które go tworzyły i pozwalały się przed nim bronić. Dziś jest klasyką polskiej humanistyki. Jestem niemal pewien, że książka Dudy również stanie się pozycją klasyczną. Przemawia za tym kilka względów.

Po pierwsze, książka jest świetnie napisana. Świetnie tzn. prosto - wywody Dudy nie stwarzają bariery językowej dla niewyspecjalizowanego odbiorcy. Dla wyspecjalizowanego mogą zaś służyć niemal za lekturę plażową. Nie znaczy to, że Dudzie brakuje warsztatu, przeciwnie - ogromna bibliografia zawarta na końcu książki zaświadcza, że za autorem stoi rozległa i godna pozazdroszczenia erudycja. A także wielka praca włożona w to, żeby tekst nas po prostu wciągnął (nieprzypadkowo, sądzę, jednym z mentorów na drodze myślowej badacza jest Tadeusz Boy-Żeleński, autor Naszych okupantów i Dziewic konsystorskich).Względna przystępność książki Dudy jako efekt cyzelatorskiej pracy autora sprawia, że Dogmat ptci ma szansę stać się książką ważną w wymiarze szerszym niż naukowy - podobnie jak w przypadku Marcowego gadania książka ma potencjał wytwarzania przeciwciał wobec nienawistnej mowy sączącej się dziś zewsząd i chronionej państwowym i kościelnym imprimatur.

Drugi argument przemawiający za moją tezą łączy się z tym, że Duda sięgnął pod latarnię, czyli tam, gdzie najciemniej. My - pozwalam sobie na tę uogólniającą formułę - badacze zajmujący się problematyką gender oddaliśmy (z nielicznymi wyjątkami) pole debaty publicznej niemal walkowerem. Prowadzimy swoje badania, zamykamy się w wieży z kości słoniowej, sarkamy na jakość dyskusji, z której coraz bardziej nas się wyklucza lub ustawia na straconej, a tak lubianej przez media, pozycji dziwaków-lewaków. Być może liczymy, że to uniwersytet jest przestrzenią, w której kształtują się umysły młodych Polaków i przemycamy im naszą wiedzę podczas ćwiczeń i wykładów, podpowiadamy lektury i dyskutujemy z tym, co w głowy młodzieży wlano podczas niezliczonych godzin katechezy. Mylimy się. Duda, który jest nie tylko akademikiem, ale także działaczem społecznym i aktywistą profeministycznym, ma szerszą perspektywę. Być może ona właśnie zaważyła na tym, że zdecydował się skrupulatnie śledzić wystąpienia uczestników antygenderowej krucjaty, by odkryć reguły rządzące ich retoryką i językiem 
(„Głównymi aktorami - pisze - niniejszego tomu pozostają język i retoryka”, s. 10). Wielu z nas wydają się one przezroczyste i, co tu owijać w bawełnę, toporne, a przez to niewarte uwagi. W Dudzie jest więcej pokory, Duda myśli inaczej - nie szczędzi trudu by brnąć pod prąd antygenderowego bluzgu, bo wszakże na bluzgu się (na razie) skończyło ${ }^{3}$ i odkryć jego, jak się okaże bardzo skąpo kapiące źródła (cała argumentacja antygenderowa ogranicza się do coraz mniej wiernego przywoływania 2 pozycji: książek Gabriele Kuby i Marguerite A. Peeters, a także - $\mathrm{w}$ warstwie retorycznej - przedwojennej homiletyki kardynała Hlonda). Nie zapomina także wymapować „drogi i wpływy poszczególnych antygenderystów”, które „się nie przecinają” a „ten nieuchwytny podział ukazuje [...] personalne i instytucjonalne uwikłania" które „odsłania też siatka wzajemnych cytatów, ewentualnie ich brak” (s. 12).

Trzecia przyczyna, dla której tak wysoko lokuję pracę Dudy, łączy się z jej aktualnością. „W roku $2012 \mathrm{w}$ polskich mediach katolickich ukazały się pierwsze prezentacje i komentarze dotyczące gender studies i polityki równościowej Unii Europejskiej" - tym zdaniem rozpoczyna Duda swój obszerny wywód, wskazując przy tym wyraźnie, że "gender" jest wrogiem wynalezionym na potrzeby chwili, wrogiem wyciągniętym niczym królik z kapelusza. Następny rok, 2013, był rokiem największego nasilenia walki z tym widmowym wrogiem - genderem. Choć od 2015 roku miejsce "gendera" zajęli uchodźcy/islamiści/terroryści, to dosłownie ostatnie dni (wypowiedzi papieża Franciszka o gender, opanowanie fali uchodźczej) wskazują, że w każdej chwili można ożywić tę jakże funkcjonalną figurę (czołowi „antygenderyści" pełnią dziś ważne funkcje państwowe, a obecny minister nauki, Jarosław Gowin, arbitralnie orzeka, że „jakieś studia gejowskie i lesbijskie” nie będą finansowane z budżetu ministerstwa - w wojnie z genderem łatwo o sławę i bohaterstwo). Dudzie udało się zidentyfikować źródła i gramatykę antygenderowego języka (np. „figurę śledztwa”, s. 56, retorykę wojny s. 73 i wiele, wiele innych), obnażyć jego fałsz i wykazać manipulatorskie użycia, opisać jego inflację - w skrajnych, choć niestety bardzo licznych, przypadkach prowadzącą do sankcjonowanego powagą instytucji, np. kościelnej, bluzgu i bełkotu.

Ta recenzja, jak każda recenzja pracy tak obszernej, może być dość syntetyczna albo bardzo rozwlekła. Wydaje mi się, że najważniejsze napisałem - skłaniam się więc ku syntezie: książka Dudy jest pracą wybitną i będzie

3 Choć bluzg to jak najbardziej performatywny, czego świadectwem uchwały różnych rad miejskich i pedagogicznych uwalniające instytucje, których owe rady są emanacjami, od "gendera". 
czytana jako analiza nienawistnej i propagandowej mowy długo po tym, jak mowa ta wybrzmi. Bo jest to po prostu analiza wzorcowa. Wyobrażam sobie np., że badacz dyskursu publicznego analizujący wypowiedzi skierowane przeciw uchodźcom może z dużym pożytkiem przeczytać Dudę jako inspirację, podejrzeć warsztat autora Dogmatu płci.

Miast pieczołowitego rekonstruowania wywodu Dudy, chciałbym pokusić się o refleksję ogólną, która wyłania się z jego książki. Zanim do niej dojdę, muszę skupić się na jednej, być może najważniejszej, kwestii, jaka z Dogmatu ptci się wyłania. Otóż autor Dogmatu... bardzo dba o to, by jego opis, przy całej jego potoczystości, był chłodny i naukowy. Stawia wysokie wymagania sobie, ale także tekstom uczestników antygenderowej krucjaty, wśród których prominentne miejsce zajmują postaci polskiego kościoła - ksiądz Dariusz Oko, ksiądz profesor Paweł Bortkiewicz, kardynał Henryk Hoser. Charakterystyczną cechą ich wystąpień jest coś, co Duda nazywa „stylizowaniem na naukowość". Owa stylizacja wyraża się m.in. obecnością przypisów, przywoływaniem różnych danych liczbowych i statystyk etc. Wreszcie za naukowością przemawiają stopnie i tytuły, którymi ci autorzy się posługują. Dlaczego jednak pisze Duda o stylizacji?

Język naukowy aspiruje do obiektywności, język stylizowany na naukowy niedbale obiektywność symuluje, a w istocie rzeczy jest niezwykle mocno wartościujący. Język naukowy dąży do precyzji i prawdy, język symulujący naukowość jest językiem manipulacji. Jest jak aktor grający dentystę w reklamie pasty do zębów: może przekona do jej zakupu, ale z bolącym zębem do niego nie pójdziemy. Duda za Katarzyną Pokorny-Ignatowicz wskazuje, że podstawowa dla "antygenderowej” krucjaty wypowiedź Benedykta XVI z 2012 została przekłamana w przekazie KAI - tam gdzie papież (którego język według Dudy „daleki od ideologizacji”) mówił o „filozofii gender zgodnej z antropologiczną rewolucją" (s. 146) komunikat KAI i komentarze kard. Hosera informowały już o „ideologii gender”. Zmieniając „filozofię” na „ideologię" dokonano istotnego przesunięcia semantycznego: z filozofią można dyskutować, ideologię trzeba zwalczać - w imię jakiejś domniemanej „nieideologicznej" prawdy. Małe przekłamanie, ale pozwala ogłosić alarm - umówmy się filozofią mało kto się przejmuje, ale ideologią przejmą się wszyscy. Maszyna została uruchomiona.

Istotą działalności naukowej jest krytycyzm wobec danych, źródeł, wyników etc. Stylizacja naukowa przyjmuje dane bezkrytycznie i niezwykle wybiórczo - po to by podtrzymać założone wyjściowe tezy. Duda rekonstruuje działanie tej stylizacji - właściwie wszystkie „merytoryczne” argumenty 
prominentnych antygenderystów można odnaleźć w, delikatnie rzecz ujmując, eseistycznych książkach wspomnianych już autorek - Gabriele Kuby i Marguerite Peeters. Sięgając do tych źródeł, Duda przeprowadza ich konsekwentną krytykę - żadna z publikacji nie spełnia podstawowych kryteriów naukowości. Uruchomiły one jednak lawinę wypowiedzi, których ton staje się, jak w przypadku księdza Oko, coraz bardziej prostacki i agresywny. Wprawiona w ruch maszyna pracuje pełną parą. Uprawianie nauki wymaga rzetelności badawczej. Dotyczy to nauk ścisłych przyrodniczych, społecznych, a także humanistycznych. Komentując Heideggera powinienem go przeczytać - najlepiej ze zrozumieniem. Wydaje się, że badacz będący duchownym i profesorem etyki powinien ową rzetelność cenić szczególnie wysoko, a prawdę uznawać za wartość najwyższą. Profesor Bortkiewicz, bo o nim tu mowa, nie uprawia krytyki gender studies, ale - niezbyt zręcznie - stylizuje jej uprawianie. Duda przyłapuje Bortkiewicza na dość niskim przekłamaniu - katolicki filozof twierdzi, że cytuje Uwikłanych w płeć Judith Butler, ale „próba weryfikacji ujawnia, że wskazane źródło nie jest tożsame z tekstem, który przytacza etyk. Ów cytat, a tak naprawdę omówienie myśli Butler, w przeciwieństwie do etyka profesora, prawidłowo zdekodował inny antygenderysta - opisany wcześniej Grzegorz Strzemecki w publikacji Gender - ideologia państwowa Rzeczpospolitej (2014). Źródłem 'cytatu' okazują się materiały szkoleniowe piszącego te słowa [tj. samego Macieja Dudy - W.Ś.]” (s. 366). Niepoważne - to najdelikatniejsze ze słów, jakie cisną się na usta jako komentarz dla tego typu hochsztaplerstwa. Pracująca maszyna to prawdziwe perpetuum mobile - energię czerpie sama z siebie.

Nauka ma charakter kumulatywny i progresywny, stylizacja naukowa niczego nie kumuluje i nie zakłada progresji. Publikacje antygenderowe tworzą „kulę śniegową niepotwierdzonych i niezweryfikowanych danych” (s. 406). Powstaje ni to lawina, ni to wydmuszka. Wydmuszka, bo „proceder obrazuje proces rozpowszechniania narracji głoszonej przez księży, którzy sprzeciwiają się 'ideologii gender'. Ów mechanizm sprawia, że mimo zalewu antygenderowych publikacji często do czynienia mamy nie tylko z tymi samymi hipotezami, ale też z tymi samymi tekstami, których wielokrotna publikacja nie przyczynia się do rozwoju dyscypliny ani nie obrazuje przyrostu wiedzy jej autorów" (s. 361) Działająca maszyna - perpetuum mobile - energii nie pobiera, ale też nie wytwarza... I teraz zapowiedziana refleksja: ogólny obraz, jaki się wyłania z analiz Dudy, jest w gruncie rzeczy bardzo smutny. Autor bardzo stara się, żeby jego książka nie wybrzmiała antyklerykalnie, ale im bardziej się stara, tym bardziej widać, że trudno nie odczuwać niechęci wobec 
Kościoła, który w swoim głównym nurcie staje się coraz bardziej radiomaryjny, ksenofobiczny i nienawistny wobec wszelkiego odstępstwa od jego nader konserwatywnej wizji świata.

Kościół jest bardzo ważnym aktorem debaty publicznej w Polsce. Być może nawet najważniejszym. Ów aktor jest dramatycznie nieprzygotowany na wyzwania współczesnego świata. Język, a szerzej rzecz ujmując, strategia komunikacyjna, jaką się posługuje, jest zarazem kompletnie nieskuteczna, gdy nazywa problem, i niezwykle skuteczna, gdy mobilizuje i kanalizuje (w sensie: „kieruje”, ale także, niestety, sprawia, że stają się bardzo niskie) emocje. Bez względu na to, czy jesteśmy z Kościołem związani czy nie, powinniśmy być zatroskani tym stanem rzeczy. Nawet nie będąc katolikiem, chciałbym, żeby Kościół, do którego należy zdecydowana większość moich rodaków, wykonał intelektualną pracę przyswojenia sobie tego, czym w istocie jest gender i zajmująca się genderem dyscyplina badawcza, nim zacznie ustami swoich prominentnych przedstawicieli szafować argumentami ad hitlerum pod naszym, moim, ich adresem. Innymi słowy - chciałbym, żeby ta wielomilionowa instytucja potrafiła wygenerować kogoś na kształt Dudy, kogoś, kto zada sobie trud lektury i zrozumienia tego, jak funkcjonuje płeć kulturowa i czym zajmują się badacze gender. Chciałbym, by ten ktoś, przy zachowaniu pełnego szacunku do tego, co nas różni, i godząc się, że ta różnica jest nieredukowalna, skłonił mnie do przemyślenia moich poglądów, rewizji wiedzy, poszukiwania wspólnoty ${ }^{4}$. Jak dotychczas nikt taki się nie pojawił, nieliczne „niewykluczające” głosy katolików świeckich i niektórych duchownych (ojciec Paweł Gużyński, ks. Kazimierz Sowa, publicyści „Więzi”, ,Znaku”, "Tygodnika Powszechnego", których głosy Duda skrupulatnie odnotowuje i wskazuje jako przysłowiowe światełko w tunelu), oskarżani są o „flirt z genderem" i nie są w stanie zaistnieć w potoku inwektyw.

We wstępie do swojej książki Duda zwierza się z metody i jej celu: „skupiam się na konkretnych zdaniach, próbuję rozebrać je na czynniki pierwsze. Staram się je zdekonstruować, zrozumieć jak są zbudowane i dlaczego brzmią w publicznej przestrzeni. Myślę, że w ten sposób porządkuję nie tylko własne emocje" (s. 11). Dalej pisze o tym, że jego celem jest odnalezienie potencjalnych „miejsc wspólnych” w dyskusji o gender. Niestety, mam wrażenie, że nie ma ich zbyt wielu, toteż myślę raczej o tym, jak Duda uporządkował moje

4 Ciekawe propozycje w tym względzie pojawiają się w interpretacji papieskiego nauczania, jaką proponuje Edwin Bendyk na swoim blogu: http://antymatrix.blog.polityka.pl/2016/08/10/papiez-franciszek-i-gender-pana-boga/ (11.08.2016). 
emocje. Po lekturze jego książki rodzą się we mnie dwie rywalizujące ze sobą. Pierwszą z nich jest smutek - smutek, że najprawdopodobniej nikt z ",antygenderystów" książki Dudy nie przeczyta, podobnie jak nie przeczytali Butler. Drugą jest złość. Jej przyczyny są takie same - buta, arogancja, pewność siebie mandarynów wysoko ulokowanych w kościelnej i państwowej hierarchii pozwolą im przejść mimo i dalej dzielnie walczyć "genderem”, a błysk zdobytych w tej walce orderów będzie odbijał się w świetle fleszy, a flesze będą odbijały się od błyszczących orderów - perpetuum mobile...

\section{Abstract}

\section{Wojciech Śmieja}

UNIVERSITY OF SILESIA (KATOWICE)

The Anti-Gender Perpetuum Mobile

Review: Maciej Duda, Dogmat płci: Polska wojna z gender [The Dogma of Sex/Gender: The Polish War with Gender Theory], Wydawnictwo Naukowe Katedra, Gdańsk 2016, 628 pp.

\section{Keywords}

gender, sexuality, discourse, church 